\title{
The Quality of Financial Statements Antecedents and Consequences Towards Financial Accountability
}

\author{
Ni Made Dwi Karyatni ${ }^{1}{ }^{*}$, Lilik Handajani ${ }^{2}$ \\ ${ }^{1}$ BPKAD Kabupaten Lombok Tengah \\ 2 Fakultas Ekonomi dan Bisnis Unram
}

\section{A R T I C L E I N F O}

Article history:

Received 18 May 2020

Received in revised form

5 June 2020

Accepted 18 July 2020

Available online 29 August

2020

Keywords:

Competence of human

resources; Reconciliation;

Leadership support;

Completion of Audit

Findings; Quality of

Financial Statements;

Financial Accountability.
A B S T R A C. T

Based on this research, low quality of financial statement presentation, especially regional government level accounting entity. Presentation of the financial statements of the Regional Government Unit was not fully appropriate with the Governmental Accounting Standards and Accounting Policies so that affects the accuracy of the information presented in the financial statements. Inaccurate financial reports has a negative impact to users in policy decision. This study aimed to test empirically the factors that affect the quality of the financial statements and the problems were faced by regional government unit (SKPD) in preparing the financial statements and the implications for the financial accountability. The population in this research was 292 respondents. The sample was determined by purposive sampling technique amount 97 respondents including the Financial Administration Officer (PPK) SKPD, PPK staff at 44 SKPD staff and staff in accounting staff and reporting on SKPKD. Data analysis was used on Partial Least Square (PLS). The findings of this study indicate that the quality of SKPD financial statements were affected by the application of completion of audit findings, but this study is not affected by the reconciliation, competence of human resources and the leadership support. Other findings indicate that the financial statements SKPD have implications for financial accountability. The implications of this study can contribute some ideas for the Central Lombok regency government to increase financial assistance to personnel managers through education and training so that it can make good quality in the financial statements and practical contribution in formulating the direction and policies related to the accountability of local government financial reporting.

\footnotetext{
* Corresponding author.

E-mail addresses: dwikaryatni037@gmail.com (Ni Made Dwi Karyatni)
} 


\section{Introduction}

The Law Number 28 Year 1999 concerning Clean and Free of Corruption, Collusion, and Nepotism of State Administration (Undang-undang No. 28 Tahun 1999 tentang Penyelenggaraan Negara yang Bersih dan Bebas dari Korupsi, Kolusi, dan Nepotisme) states that transparency and accountability are two of several principles that must be fulfilled by the government including the regional government. Transparency and accountability are not only the responsibility of the central government but also regional governments in line with the mandate of Law Number 23 Year 2014 (Undang-undang No. 23 Tahun 2014 mengenai pemerintah daerah) concerning regional governments. There is a strong obligation and pressure from the central government so that regional governments are required to implement transparency and accountability in regional financial management.

One way to facilitate the creation of public accountability is through the presentation of comprehensive local government financial reports (Riyansa, dkk 2015). Financial reports are an important component of creating public sector accountability and it is one of the measurement instrument of financial performance of regional governments. Related to the task of upholding financial accountability, especially in the regions, regional governments are responsible for publishing financial reports to their stakeholders (Indriasari, 2008). Financial reports are a medium in delivering the information. Government financial statements are a representation of the financial position of transactions done by the government (Indriasari, 2008) The presentation of complete information in financial statements will create transparency and will later bring the accountability (Nordiawan, 2007: 5). A study conducted (Fitriyah, 2013), proved that the better presentation of regional government financial statements will increase the realization of regional financial management accountability, however, Riyansa (2015) states that the presentation of financial statements do not affect financial accountability.

The Central Lombok Regency Government is one of the reporting entities that receives the WTP title for the 2018 LKPD audit from BPK RI (www.mataram.bpk.go.id). The obtained opinion does not guarantee that the regional government is free from findings and irregularities. A weak SPI in managing regional finances and regional assets is a finding of the Central Lombok Regency LKPD investigation. The audit results of compliance with BPK RI legislation found a loss element of procurement in government goods and services, these findings indicated that the financial accountability was still low, especially in financial management integrity of regional governments. The results of the inspectorate's review of the Central Lombok District LKPD in 2018 found some weaknesses in SPI and incompatibility of financial statement presentation with SAP, which affected the quality of financial statements, including First, the implementation of accounting systems and procedures in each SKPD and SKPKD had not run in line with applicable regulations. Second, regulations did not fully support the implementation of accrual-based accounting. Third, the inappropriate presentation of financial statements with SAP. Based on BPKAD data toward the consolidation of SKPD financial statements in 2019, there were 18 SKPD of 47 SKPD received corrections on the presentation of SKPD financial statements, 17 SKPD presented incomplete financial statements and 2 SKPD did not present financial reports. These problems have an impact on the declining quality of financial statements which has implications for decreasing the level of financial accountability of regional governments.

Considering its urgency as a means of accountability, the presentation of financial statements must meet the elements of its quality characteristics as stated in PP 71 Year 2010 concerning SAP which includes relevant, reliable, comparable, and understandable. Presentation of financial statements must be able to provide relevant information to the users in making decisions so that information in financial statements must provide benefits in decision making and it can be understood by users (Xu, dkk, 2003). To increase the usefulness of financial statement information in regional government starting in 2015, the regional governments must apply the accrual basis in the presentation of financial statements in line with the mandate of Law Number 17 Year 2003 concerning State Finance junto PP 71 Year 2010 concerning SAP and the Regulation of Ministry of Home Affairs Number 64 Year 2013 concerning the application of accrual-based accounting for regional governments. The changes in accounting basis in the presentation of the financial statements have an impact on the methods and techniques of recognition, measurement, recording, and disclosure of each regional government's financial transaction. To carry out these changes, it requires the competency of human resources (HR) who have knowledge in the field of accounting to produce quality financial statement and valuable information. A study about the effect of HR competency on the quality of financial statements was conducted by Setiawati, dan Sari (2014) in which in their research found that the changes of regional financial management were able to be anticipated by regional governments, the Government Apparatus was able to understand SAP and SPIP in the presentation of financial statements, and it was not supported from a study conducted by Karmila, dan Darwis (2013)The implementation of reconciliation, which is part of an internal control system, can improve the reliability of 
regional government financial statement. PP (Government Regulation) Number 8 Year 2006 concerning Financial Reporting and Performance of Government Agency article 33 paragraph 1 states that to improve the reliability of financial and performance reports, each reporting and accounting entity is required to conduct SPI based on legislation regulation. Paragraph 2 explains that the reconciliation procedure must be made between the financial transaction data conducted by the PA/KPA and the financial transaction data are accounted by BUN / BUD in the SPI as referred to paragraph 1 . Reconciliation is one of the keys in efforts to prepare credible financial statements Pradono (2015) The effect of reconciliation on the quality of financial statements had been tested by Pradono (2015)and the results of his research found that reconciliation has a positive and significant effect on the quality of financial statements. The better intensity of reconciliation, the better quality of SKPD financial statements will be. In contrast to the results of study conducted by (Roni, 2015) the reconciliation did not affect the quality of financial statements.

BPK Audit results on the audit of regional losses settlement to the Central Lombok district government as stated in the monitoring report Number: 163 / LHPt / XIX.MTR / 12/2018 states First, the Regional loss document is not all supported by an Absolute Responsibility Certificate (SKTJM) from parties subject to treasury claims and compensation as well as have not been supported by guarantees of regional losses settlement. Second, the Secretariat of Judicial Compensation Prosecutor's Assemblies Team for Compensation Claims (MP TP TGR) for Regional Finance and Goods of Central Lombok Regency does not have monitoring data on the time to resolve the regional loss case. Third, the Head of SKPD has not reported the occurrence of regional losses to the Central Lombok Regent and has not notified the BPK within a period of seven days as stipulated in article 61 of Law Number 1 Year 2004 concerning the State Treasury. Research related to the completion of audit findings was conducted by Sari (2012) and conclude that the completion of audit findings had a positive effect on the implementation of good principle governance.

An adequate quality of financial statements can also be achieved through commitment and support from superiors as the authorities. As quoted from the Commission XI Work Visit Team Report of Republic of Indonesia (Laporan Tim Kunjungan Kerja Komisi XI DPR RI) recessing the trial period V session year 2018 - 2019 to NTB Province 1-5 August 2019 then it is disclosed that the implementation of regional financial management with SIMDA in NTB Province, it is necessary to increase in terms of regional government support and SKPD leadership (www.dpr.go.id). The existence of superior support the performance of its employees so that the financial statements are increasingly high quality. Different results were obtained by (Alfian, 2014.) who found that top management support did not affect on the quality of financial statements.

The previous study above shows the differences in the study result about the determinants factor in the quality of financial statements of Regional Government Work Unit. This is one of the reasons for researchers to examine and re-analyze the effect of HR competency, reconciliation, completion of audit findings, and support from superiors as determinants of SKPD quality financial statements in Central Lombok Regency. This study explored the determinants of SKPD quality financial statements and elaborated on the effect of quality financial statements on regional financial management accountability. Previous researchers tended to test the SPI as a whole while in this study, it explored the reconciliation variable which was an important part of the SPI, the SAP variable is proxied by the completion of audit findings, and emphasizes the quality testing of financial statements toward financial management accountability.

Based on these arguments, the following problems were formulated: First, does HR competency, Reconciliation, Completion of audit findings and superiors' Support affect the quality of financial statements? Second, does the quality of financial statements affect financial accountability? While the objective of the study was to test and provide empirical evidence regarding the effect of HR competency, reconciliation, completion of audit findings and superiors' support for the quality of financial statements. Furthermore, the objective of the study was to examine the effect of financial statements quality on financial accountability.

\section{Methods}

The data used in this study were primary data that were obtained from questionnaire instruments related to research variables. The population in this study consisted of financial management apparatuses in accounting entities and reporting entities within the Central Lombok District Government around 292. The sampling method in this study was conducted by using purposive sampling techniques, with the following criteria: Government Apparatus serving as PPK SKPD, One Staff SKPD PPK and Accounting and Reporting Staff in SKPKD so the total sample was 97 respondents. 


\section{Definition of Operational Variable}

1) Endogenous Variable

a. The operational definition of the quality of financial statements in this study is based on the qualitative characteristics of financial statements as stated in PP Number 71 Year 2010 as measured by indicators: 1) Benefits of resulted financial reports, 2) Timeliness of financial statement reporting, 3) Completeness of presented information, 4) Honest Presentation, 5) The contents of the Financial Statements can be verified, 6) Neutrality in reporting, 7) The contents of the financial statements can be compared, 8) The Financial Statements can be understood. The questionnaire consisted of 12 statements which were adapted from Roni (2015).

b. Financial accountability is the responsibility on financial integrity, disclosure, and compliance toward legislation. The targets of this accountability are the financial statements that are presented and the applicable legislation which cover the receipt, deposit, and expenditure of money by government agencies. Financial accountability indicators are measured by indicators of financial management accountability, disclosures in reporting and evaluating financial performance. The questionnaire consisted of 7 statements adapted from Sihaloho (2014)

\section{2) Exogenous Variables}

a. The HR competencies referred to in this study were the capabilities possessed by the SKPD financial management apparatus in carrying out their official duties whose indicators were adopted from Sudiarianti (2015) and Roni (2015) research, including: 1) Educational background of the regional financial management apparatus, 2) Knowledge was the knowledge possessed by a regional government financial management apparatus to do its duties and responsibilities based on the involved field 3) Skill was the ability that must be possessed by every government financial management apparatus to do a task and responsibility given by the government; 4) Training and 5) Distribution of tasks.

b. Government Number 8 Year 2006, in article 33 states that a reliable Internal Control system must be created a reconciliation procedure between financial transactions that are conducted by the Budget User/Budget User Authority with data on financial transactions that are done by the State/Regional General Treasurer. In the context of regional government, reconciliation is a process of matching data between internal SKPD, namely PPK SKPD as the compiler of financial statements with treasurer of revenue, expenditure bureau, and treasurer of goods serving as financial administration and goods controlled by SKPD, besides internal reconciliation of SKPD, the reconciliation process also includes reconciliation between the accounting entity (SKPD) and the reporting entity in this case the Regional Financial and Asset Management Agency (BPKAD) as the coordinator of financial/goods management. In this study, reconciliation was measured using two indicators adopted from Roni (2015) namely Internal Reconciliation and External Reconciliation

c. The completion of audit findings/follow-up recommendations on audit results are activities and/or decisions made by officials who are inspected and/or other parties who are competent to conduct the recommendations of BPK audits (Sari, 2012). Indicators of audit findings completion were modified based on a study conducted by (Sari, 2012), including the completion of the audit findings on the financial statements related to internal control and compliance based on legislation.

d. Superior support is the superior power toward planned goals and initiatives strategy. Operationally, superior support is the perception of financial statement compiler operators who receive special attention from several superiors as well as the involvement of superiors in the work and provide the necessary resources.

\section{Data Analysis}

This study applied data analysis method using SmartPLS software version 3.0. (Ghozali, 2015:10) explains that PLS is a method of soft modeling analysis because it does not depend on the assumption that the data must be on a scale of measurement, distribution free, and the number of certain samples, which means the number of samples can be small (under 100 samples). In this study, data analysis methods were divided into two namely:

\section{Descriptive Statistics}

According to Sugiyono (2016:21) descriptive analysis is a statistic that is used to analyze data by describing or giving the idea of data that have been collected to make valid conclusions for generalization. In this study, descriptive statistics included: preparing data in the form of tables, graphs, median calculations, mean, standard deviations, percentage calculations, and others. 


\section{Inferential Statistics}

According to Siregar (2019:2) Inferential statistics is a series of techniques that is used to study, estimate, and draw conclusions based on obtained data from the sample to describe the characteristics of a population. In this study, inferential statistics applied PLS analysis starting from the outer model, inner model, and testing the hypothesis with the following steps:

a) Conceptualization of models: Modeling in PLS consists of inner and outer models (Abdillah, 2015:193) Outer model (measurement model) describes the relationship of indicators with latent variables, while the inner model (structural model) describes the relationship between two latent variables.

b) Determining the algorithm analysis method; In PLS with SmartPLS 2.0 M3 program and SmartPLS 3.0 M3, the algorithm analysis method is only PLS algorithm with three schemes, namely factorial, centroid, and path (Ghozali, 2015:2) This study applied PLS path or structural weighting algorithm scheme

c) Determining the resampling method; this study applied bootstrapping method because this method was more often used in structural equation models and only Smart PLS 3.0 program provided bootstrapping resampling methods

d) Determining the path diagram; the path diagram in this study can be seen in Figure 1 .

\section{Measurement model or outer model}

An outer model evaluation is conducted to assess the validity and reliability of the model. Outer models with reflexive indicators are evaluated through convergent validity, discriminant validity, and composite reliability Ghozali (2015) Convergent validity test can be seen from the loding factor value must be more than 0.7 for confirmatory research and 0.6-0.7 for exploratory research is still acceptable. Discriminant validity can be seen by comparing the square root of AVE for each construct with the correlation value between two constructs in the model. The validity of discrimination is good if the square of AVE for each board is greater than the correlation between constructs in the model (Fornnel and Larcker, 1981 in Ghozali, 2015).

Besides the validity test, the measurement model is also conducted to test the reliability of a construct. The reliability test is done to prove the consistency and accuracy of the instrument in measuring the construct. Reliability testing in SmartPLS 3.0 can be done in two ways, namely composite reliability and Cronbach's alpha (Ghozali, 2015:75). Rule of thumb alpha value and good composite reliability must be greater than 0.7. Although the value is 0.6, it is still acceptable (Hair et al, 2012 in Ghozali, 2015).

\section{Structural Model or Inner Model}

The assessment of structural models with PLS starts with looking at the value of R2 for each endogenous latent variable as the predictive power of the structural model. $\mathrm{R} 2=0.67,0.33$ and 0.19 indicate that the model is strong, moderate, and weak (Chin 1998 in Ghozali, 2015:79). Q square predictive relevance for the structural model is used to measure how well the observational values generated by the model and also the estimated parameters. $Q$ square value more than 0 indicates that the model has a good predictive relevance, and vice versa if the $Q$ square value is less than or equal to 0 , it indicates the model has less predictive relevance.

\section{Hypothesis test}

If the T-statistic coefficient in the PLS 3.0 Path Coefficient output table (T-count) shows a greater coefficient $(>)$ than the t-table (1.66), then this result illustrates that the variable is significant and it means that the latent variable influence significantly against other variables..

\section{Result And Discussion}

\section{Respondent Characteristics}

Characteristics were classified based on gender, the number of female respondents was greater than men at 56\%, and it indicates the existence of gender equality in the task of financial management in Central Lombok Regency. Based on the average age of respondents at the age of 25-45 years, it indicated that the age of the apparatus preparing the financial statements was at productive age. The tenure as ASN and the tenure as financial manager of the respondent data showed $43 \%$ and $62 \%$ of respondents had tenure as ASN more than 10 years and more than 4 years as financial manager. In terms of the respondent intellectuality, it is seen from the level of education that $66 \%$ of respondents had received an undergraduate education so that they can easily understand their duties as compiling SKPD financial statements. Judging from the participation of respondents in financial training, data showed that $26 \%$ had 
attended training only once, and 15\% had never attended training from 95 respondents, this was due to the lack of training implementation by the government of Central Lombok Regency.

\section{Description of Research Variables}

The description of the research variables was shown from the obtained results based on respondents' answers to each indicator measuring variables. Interval values of the frequency distribution were obtained from the formulation as follows:

\section{Interval $=\frac{\text { Nilai Tertinggi }- \text { Nilai Terendah }}{\text { Jumlah kelas }}$}

Scores for each alternative answer from the research variables have been determined with a minimum value of 1 and maximum of 4 so the obtained interval value was 0.75 . The criteria used to determine the condition of the research variables as a whole can be seen through the average score as follows: a) Very Poor (1.00 - 1.75); b) Poor (1.76 - 2.50): c) Good (2.51 - 3.25); d) Very Good (3.26 - 4.00).

Respondents' answers to the variable of financial accountability was good with an average variable score of 3.07. The variable quality of financial statements with an average value of 3.16 was relatively good, indicating that the SKPD financial statements in Central Lombok Regency have been already good but not yet optimal in terms of timeliness of presentation. The HR competency variable had an average value of the variable which was classified as good, namely 3.18, which means that respondent ratings were classified as good. Similar case with respondents' answers to the reconciliation variable with an average score of 3.33. The variable completion of audit findings had a mean score of 3.15, which means that the respondents' evaluation of the audit findings follow-up was good. The evaluation of respondents' answers to superiors' support was classified as good with a score of 3.31 which means there is good support from superiors.

\section{PLS Test Results}

PLS test results in this study included outer model evaluation with the reflective model and the inner model with a significance of $5 \%$.

\section{1) Outer Model}

Based on the outer model test results through the Alogaritm menu on PLS, there were still two indicators which had values below 0.6, namely indicators SDM1 and SDM2 on the HR competency variable with a loading factor value of 0.376 and 0.500 , and also there were two indicators that have values below 0.6 namely the KLK2 and KLK3 indicators on the variable of quality financial statements with loading factors values of 0.371 and 0.535 . It means that the two indicators do not meet the convergent validity so they must be removed from the model. Then, it was proceeded to the second stage of allogical analysis. The results of the outer model on the second stage showed that there was still one indicator that did not meet convergent validity. It was SDM5 indicator on the variable quality of financial statements with a value of $0.534<0.6$ so that the third stage of allogarithm test must be performed. The results of the outer model evaluation on the third stage showed that all indicators had a loding factor value more than 0.6.

Furthermore, reflective indicators need to be tested for discriminant validity as measured by looking at the average variance extracted values and the values between constructs as seen in Table 1

Table 1. Correlation between Variables and Roots AVE

\begin{tabular}{cccccccc}
\hline & Value of AVE & AK & DA & KLK & TA & RK & SDM \\
\hline AK & 0.805 & $\mathbf{0 , 8 5 0}$ & & & & & \\
\hline DA & 0.916 & 0,128 & $\mathbf{0 , 8 6 7}$ & & & & \\
\hline KLK & 0.874 & 0,501 & 0,337 & $\mathbf{0 , 7 8 2}$ & & & \\
\hline TA & 0.908 & 0,454 & 0,143 & 0,418 & $\mathbf{0 , 9 5 7}$ & & \\
\hline RK & 0.925 & 0,121 & 0,629 & 0,219 & 0,042 & $\mathbf{0 , 9 6 4}$ & \\
\hline SDM & 0.499 & 0,180 & 0,464 & 0,294 & 0,214 & 0,353 & $\mathbf{0 , 8 0 4}$ \\
\hline
\end{tabular}

Table 1 above showed that the indicators of each reflective of each construct were valid based on the discriminant validity test, namely ave values above 0.5 , the value of AVE roots, and the correlation of constructs with measurement items (indicators) were greater than the size of the construct with other 
constructs. After the validity test was continued with the reliability test of a construct. Reliability test was done by looking at the value of Composite Reliability. The reliability composite values were above 0.7 , as seen in Table 2

Table 2. Composite Reliability

\begin{tabular}{cc}
\hline Construct & Composite Reliability \\
\hline AK & 0.886 \\
DA & 0.937 \\
KLK & 0.904 \\
TA & 0.956 \\
RK & 0.963 \\
SDM & 0.780 \\
\hline
\end{tabular}

\section{2) Evaluation of Structural Model (Inner Model)}

The coefficient of determination $R$ square $\left(R^{2}\right)$ was used to assess the goodness of fit to certain exogenous latent variables toward endogenous latent variables. The higher R-square value means that the prediction model from the proposed research model is better (Abdillah, 2015:197). (See Table 3)

Table 3. R-Square

\begin{tabular}{cc}
\hline Variable & R Square \\
\hline AK & 0,251 \\
\hline KLK & 0,262 \\
\hline
\end{tabular}

Table above showed that variable construct of Financial Statement Quality can be explained by variable construct of competency of Human Resource, Reconciliation Implementation, Audit Finding, and Superior Support around 26.70\%, meanwhile 73.30\% (100-26.70\%) was explained by other variables that were not researched. Variable construct of financial accountability can be explained by variable construct KLK around 25.10\%. On the other side, around 74.90\% (100-25.10\%) of financial accountability variable was explained by other variables that were not researched.

\section{Hyphothesis Test}

The result of hypothesis test can be seen in Tabel 4 Estimate for Path Coefficients as follows.

Table 4. Path Coefficients (Mean, STDEV, T-Values, P-Values)

\begin{tabular}{cccccl}
\hline & $\begin{array}{c}\text { Original } \\
\text { Sample (O) }\end{array}$ & $\begin{array}{c}\text { T Statistics } \\
(\text { O/STERR) }\end{array}$ & P Values & $\begin{array}{c}\text { Hyphothes } \\
\text { is }\end{array}$ & Description \\
\hline SDM - > KLK & 0,104 & 0,953 & 0,341 & $\mathrm{H}_{1}$ & $\mathrm{H}_{1}$ rejected \\
\hline RK - > KLK & 0,030 & 0,192 & 0,848 & $\mathrm{H}_{2}$ & $\mathrm{H}_{2}$ rejected \\
\hline TA - > KLK & 0,363 & 3,261 & 0,001 & $\mathrm{H}_{3}$ & $\mathrm{H}_{3}$ accepted \\
\hline DA - > KLK & 0,218 & 1,467 & 0,143 & $\mathrm{H}_{4}$ & $\mathrm{H}_{4}$ rejected \\
\hline KLK - > AK & 0,501 & 4,565 & 0,000 & $\mathrm{H}_{5}$ & $\mathrm{H}_{5}$ accepted \\
\hline
\end{tabular}

From the table above it can be seen that there are t-statistic value, the relationship of significance p-value relationship between variables, and the coefficient values of each variable. The structural model equation was obtained from the results of testing the inner model and testing the hypothesis, as follows:

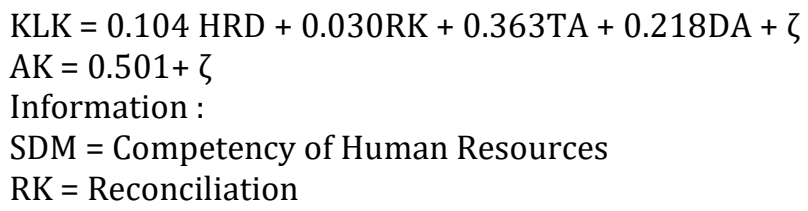


$\mathrm{TA}=$ Audit Findings

DA = Superior Support

KLK = Quality of SKPD Financial Statements

AK = Financial Accountability

The final structural model in this study is shown in Figure 1 below:

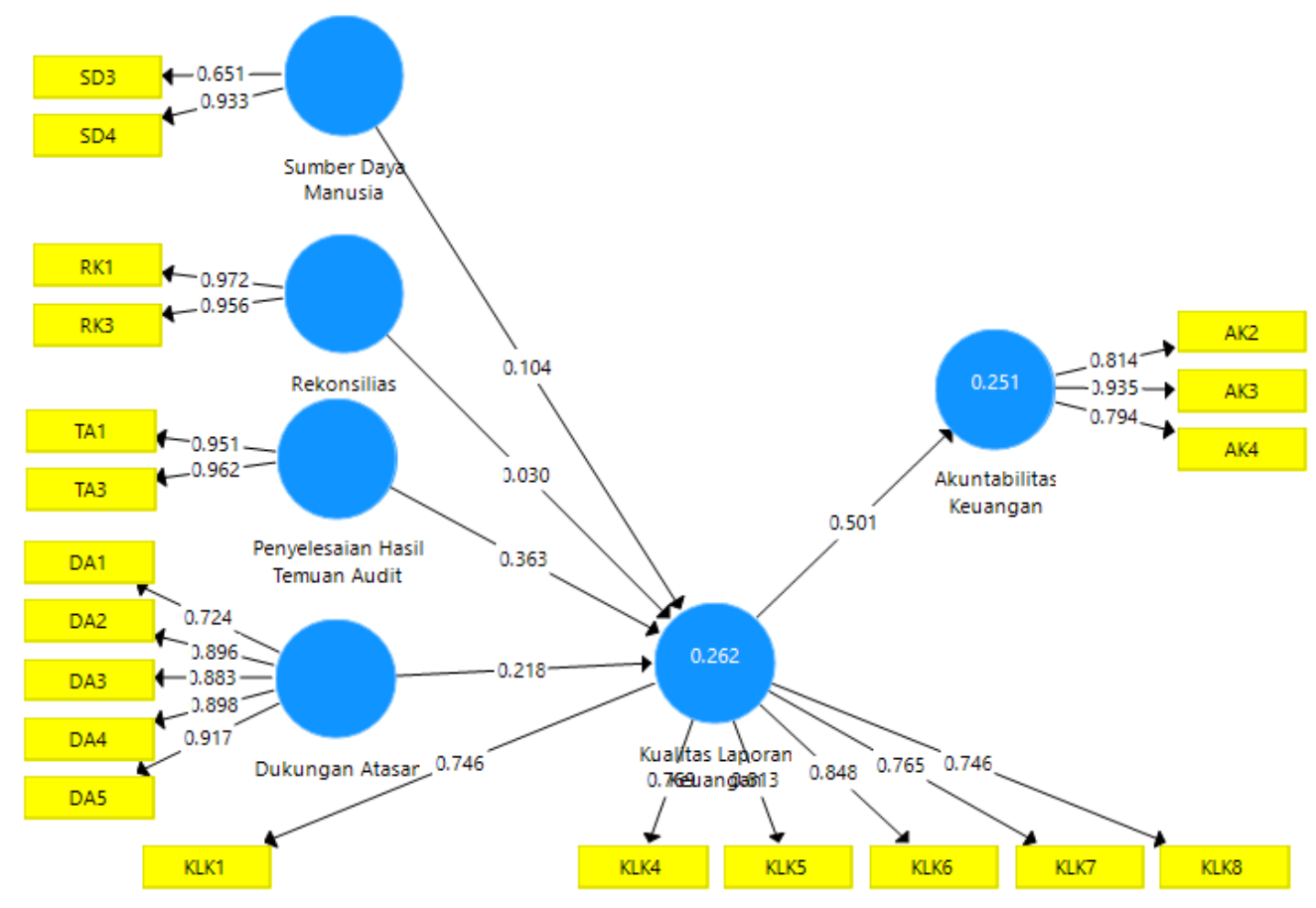

Figure 1. The Final Structural Model

\section{The Interpretation of Hypothesis Testing Results}

The effect of human resource competency on the quality of SKPD financial statements

Berdasarkan hasil uji statistik dalam penelitian ini diperoleh T-statistics sebesar 0,953 lebih kecil dari T-table 1,665 dengan signifikansi 5 (lima) persen (one tailed), atau nilai sig 0,341 lebih besar dari nilai $\alpha 0,05$ hal ini menunjukkan bahwa kompetensi SDM berpengaruh positif tidak signifikan terhadap kualitas laporan keuangan SKPD di Pemerintah Kabupaten Lombok Tengah. Hal ini disebabkan karena masih minimnya aparatur pengelolaan keuangan yang berlatar belakang pendidikan akuntansi yang ada di SKPD, pemahaman akuntansi hanya didominasi oleh aparatur yang bertugas di BPKAD, intensitas pelatihan yang belum optimal dilaksanakan dan uraian tugas yang belum jelas terhadap aparatur yang bertugas menyusun laporan keuangan sehingga masih terdapat pegawai yang rangkap tugas. Hasil penelitian ini didukung oleh penelitian Erniati (2015), Roni (2015) dan (Fikri, 2015) namun tidak sejalan dengan penelitian Evicahyani (2015).

Competency in accounting is as a set of knowledge, skills, and attitudes for someone to work as an accountant (Jing 2008 in Sudiarianti, 2015). Competent human resources (HR) will be able to understand accounting logic well. The failure of regional government human resources in understanding and applying accounting logic will have an impact on the errors of financial statements that are made and the discrepancies of reports with the standards set by the government (Widyantini, 2008).

Based on the statistical test results in this study, the T-statistics of 0.953 was smaller than the Ttable of 1.665 with a significance of 5 (five) percent (one tailed), or a sig value of 0.341 was greater than the value of $\alpha 0.05$, it indicates that HR competency has no significant positive effect on the quality of SKPD financial statements in the Central Lombok Regency Government. It was due to the lack of financial management apparatus with a background of accounting education in the SKPD, accounting understanding was only dominated by officials who work at BPKAD, training intensity that had not been optimally implemented and job descriptions that were not clear for preparing financial reports so there were still employees who had double duties. The results of this study are supported by research by Erniati (2015), Roni (2015) and (Fikri, 2015) but it is not in line with Evicahyani (2015) research. 


\section{The Effect of Reconciliation on the quality of SKPD financial statements}

Reconciliation is one of the key efforts to prepare credible financial statements (Pradono, 2015). Roni (2015) reveals that reconciliation is one process to ensure that all transactions have been recorded correctly by both parties before preparing financial statements. In this study, the statistical test results obtained a T-statistics of 0.192 smaller than the T-table of 1.665 with a significance of 5 (five) percent (one tailed), or a sig value of 0.848 greater than a value of $\alpha 0.05$. The statistical test results means that reconciliation has a positive and not significant effect on the quality of SKPD financial statements. The results of this study illustrate that the implementation of internal and external reconciliation has not yet made a maximum contribution in the presentation of SKPD's financial statements or regional government. It is because the implementation of internal and external reconciliation has not been done on time so that it affects the timeliness of financial statement presentation. The results of this study are in line with the research conducted by Roni (2015) but are not supported by the results of the study conducted by Pradono (2015).

\section{The Effect of completion of audit findings on the quality of financial statements.}

The completion of audit findings or what is commonly referred to as a follow-up recommendation of audit results is the activities and/or made by officials who are inspected and/or other parties who are competent to carry out the recommendations of BPK audit results. Without follow-up from authorized parliament, the executive, the audited agency, and the apparatus to carry out investigations, the examination will be ineffective and accountability will only be a dream. Based on the results of statistical tests, the effect of the completion of audit findings on the quality of SKPD financial statements obtained the parameter coefficient of 0.363 and the value of T-statistics 3.261> 1,665 (T-table) with a significance of 5 (five) percent (one tailed), which means that the completion of the findings audit is positive and has significant effect on the quality of SKPD financial statements in this study. Based on the results of these tests, it indicates that the better follow-up on the completion of audit findings will increase the quality of SKPD financial statements in the Central Lombok Regency Government. The results of this study are in line with previous studies conducted by Sari (2012) which show that the completion of audit findings has a positive and significant effect on the quality of financial statements

\section{The Effect of Superiors Support on the quality of SKPD financial statements.}

The logic in this study is that superiors provide good direction to their employees in working, maximizing two-way communication so that it prevent the miscommunication between superiors and subordinates, and superiors optimize in building the motivation and confidence of subordinates so that the readiness of subordinates to work is high. The results of this study indicate that superiors support has no effect on the quality of financial statements, indicating that the fourth hypothesis $\left(\mathrm{H}_{4}\right)$ in this study was not proven at the significance level of 5\%. According to (Sugiyono, 2016) the implications of superiors support will enhance the leader-member relationship that can support the achievement of expected organization goals. However, it turn to the opposite side, in fact, the support of superiors has no effect on the output of financial information as the goal of organization. This study does not support a study conducted by (Alfian, 2014) which states that superiors support influences the quality of financial statements. However, this study is in line with a study conducted by Alfian (2017) which states that superiors support does not affect the quality of financial statements.

\section{The Influence of the quality of SKPD financial statements on financial accountability.}

Public sector accounting has the main role to prepare financial statements as a form of public accountability (Mardiasmo, 2009:159)Presentation of complete information in financial statements will create transparency and later create accountability (Nordiawan, 2007) In this study, the statistical test results on the effect of the quality of SKPD financial statements on financial accountability obtained the results of the parameter coefficient 0.501 and the value of T-statistics 4.565> 1.665 (T-table) with a significance of 5 (five) percent (one tailed), it means that the last hypothesis in the study which states that the quality of SKPD financial statements has a positive effect on financial accountability cannot be rejected, due to the increased quality of the presentation of SKPD financial statements and regional governments will have implications for increasing accountability in regional financial management. The results of this study are supported from a study conducted by Zeyn (2011) and Fitriyah (2013) which states the better the quality of financial statement presentation will get the better the level of financial accountability of an entity. The results of this study do not support a study conducted by Riyansa et al., where the quality of financial statements does not affect financial accountability. However, it is not supported from a study conducted by (Riyansa, dkk 2015) where the quality of financial statements does not affect financial accountability 


\section{Conclussion}

The results of this study provide evidence that competency of human resources does not affect the quality of SKPD financial statements. The number of apparatus from an accounting background in each SKPD is still limited, apparatus rotation policies are not based on existing competency, training intensity is still limited and the division of tasks is unclear so that there are still multiple tasks. The results of this study also provide evidence that reconciliation has a positive but not significant effect on the quality of financial statements. The implementation of internal and external reconciliation has not provided a maximum contribution in the presentation of the SKPD's financial report or the Regional Government. This study provides evidence that the completion of audit findings has a positive and significant effect on improving the quality of financial statements which means that the completion of audit findings can improve the quality of financial statements. This study also proves that superior support has a positive but not significant effect on the quality of financial statements. It means that whether or not a lot of support from superior, it does not affect whether or not the quality of financial statements. Operators of the financial statements compiler are still able to do the work of preparing financial statements without more interference from their superiors. The results of this study also prove that there is a significant effect between the quality of financial statements and the level of financial accountability. The better quality of financial statement presentation in terms of disclosure of successes and failures in the management of financial resources shows the level of financial accountability is quite high.

\section{Reference}

Abdillah, J. (2015). Partial Least Square. Alternatif Structural Equation Modeling (SEM) dalam Penelitian Bisnis. Yogyakarta: ANDI.

Alfian, M. (n.d.). Analisis Faktor Pendukung Implementasi SIMDA dan Pengaruhnya terhadap Kualitas Laporan Keuangan Pada SKPD ( Penelitian Pada SKPD di Lingkungan Pemerintah Daerah Kabupaten Kulon Progo) 3rd Economics \& Business Research Festival 13 November 2014. 2014.

Erniati. (2015). Pengaruh kompetensi sumber daya manusia (SDM), Sistem Pengendalian Internal (SPI) dan kebijakan akuntansi terhadap kualitas laporan keuangan SKPD Kabupaten Bulukumba. Universitas Hasanuddin.

Evicahyani. (2015). Analisis faktor-faktor yang mempengaruhi kualitas laporan keuangan Pemerintah Daerah Kabupaten Tabanan. Universitas Udayana.

Fikri, D. (n.d.). 2015 Pengaruh Penerapan Standar Akuntansi Pemerintahan,Kompetensi Aparatur dan Peran Audit Internal Terhadap Kualitas Informasi Laporan Keuangan dengan Sistem Pengendalian Interen sebagai Variabel Moderating. Jurnal Universitas Mataram.

Fitriyah. (2013). Pengaruh Sumber Daya Manusia terhadap Kualitas Penyajian Laporan Keuangan dan Implikasinya terhadap Akuntabilitas Keuangan Pemerintah Daerah Kota Suka Bumi. Skripsi Sarjana yang tidak dipublikasikan. Universitas Pendidikan Indonesia.

Ghozali, D. (2015). Partial Leas Square,Konsep, Tehknik dan aplikasi menggunakan Program SMARTPLS 3.0 Untuk penelitian Emperis. Semarang: Badan Penerbit UNDIP.

Indriasari, N. (2008). Pengaruh kapasitas sumberdaya manusia, pemanfaatan teknologi informasi, dan pengendalian intern akuntansi terhadap nilai informasi pelaporan keuangan pemerintah daerah (studi pada pemerintah kota palembang dan kabupaten ogan ilir). SNA XI Pontianak.

Karmila, D. (2013). Pengaruh kapasitas sumber daya manusia, pemanfaatan teknologi informasi, dan pengendalian intern terhadap keterandalan pelaporan keuangan pemerintah daerah (studi pada pemerintah provinsi riau). Vol 9 No 1 April hal Lembaga Penelitian Universitas Riau. SOROT, Jurnal, $9(1), 1-121$.

Mardiasmo. (2009). Akuntansi Sektor Publik. Yogyakarta: ANDI.

Nordiawan, D. (2007). Akuntansi Pemerintahan. Salemba Empat: Jakarta. 
Pradono, B. (2015). Kualitas Laporan Keuangan Pemerintah Daerah: Faktor yang mempengaruhi dan Implikasi Kebijakan (Studi Pada SKPD Pemerintah Provinsi Jawa Tengah). Jurnal Bisnis Dan Ekonomi (JBE), 22(2), $188-200$.

Riyansa, D. (2015). Pengaruh Penyajian Laporan Keuangan dan Aksesibilitas Laporan Keuangan terhadap Akuntabilitas Pengelolaan Keuangan Daerah (Studi Empiris Pada Pemerintah Kabupaten Padang Pariaman). Jurnal Fakultas Ekonomi Universitas Bung Hatta, 7(1).

Roni, M. (2015). Determinan Kualitas Laporan Keuangan Satuan Kerja Di Wilayah Pembayaran Kantor Pelayanan Perbendaharaan Negara Mataram. Universitas Mataram.

Sari, D. (2012). Pengaruh Pengendalian Internal terhadap Transparansi Laporan Keuangan Pemerintah Daerah. Jurnal Seminar Nasional Akuntansi Dan Bisnis.

Setiawati, dan S. (2014). Kualitas pelaporan keuangan pemerintah daerah ditinjau dari sumber daya manusia, pengendalian intern, pemanfaatan teknologi informasi dan pemahaman akuntansi (Studi Empiris Pada Pemerintah Kabupaten dan Kota di Wilayah Eks Karesidenan Surakarta). Seminar Nasional Dan Call for Paper Program Studi Akuntansi.

Sihaloho. (n.d.). Faktot-faktor yang mempengaruhi Akuntabilitas Keuangan Pemerintah Provinsi Sumatra Utara. Universitas Sumatra Utara.

Siregar. (2019). Pengaruh Pengungkapan Enterprise Risk Management, Intellectual Capital, Corporate Social Responsibility, Dan Sustainability Report Terhadap Nilai Perusahaan. Jurnal Bisnis Darmajaya, 5(2), 53-79.

Sudiarianti, D. (2015). Pengaruh kompetensi sumber daya manusia pada penerapan sistem pengendalian intern pemerintah dan standar akuntansi pemerintah serta implikasinya pada kualitas laporan keuangan pemerintah daerah. Jurnal Simposium Nasional Akuntansi XVIII Medan.

Sugiyono. (2016). Metodologi Pendidikan. Bandung: Alfabeta.

Xu, D. (2003). Key Issues of Accounting Information Quality ManagementAustralian case studies. Industrial Management \& Data System, 103(7), $461-470$.

Zeyn, E. (2011). Pengaruh Penerapan Good Governance dan Standar Akuntansi Pemerintahan terhadap Akuntabilitas Keuangan. Trikonomika, 10(1), 52-62. 